\title{
The investigation of the relationship between perceived freedom and brief resilience: The role of participation in physical activity
}

Authors' Contribution: A Study Design

B Data Collection

C Statistical Analysis

D Data Interpretation

E Manuscript Preparation

F Literature Search

G Funds Collection

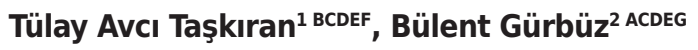 \\ ${ }^{1}$ Department of Physical Education and Sports, Faculty of Education, \\ Nevsehir Hacı Bektaş Veli University, Nevsehir, Turkey \\ 2 Department of Sports Management, Faculty of Sports Sciences, \\ Ankara University, Ankara, Turkey
}

\section{abstract}

Background: This study was designed to examine the relationship between perceived freedom in leisure and psychological resilience of university staff.

Material and methods: The sample group of the study was composed of 189 academic and 81 administrative university staff $\left(M_{\text {age }}=36.11 \pm 7.34\right)$. Participants were assessed based on the "Perceived Freedom in Leisure Scale (T-PFLS)" and the "Brief Resilience Scale (T-BRS)". ANOVA, independent samples t-test, and Pearson correlation analysis methods were used to analyze the data.

Results: T-test analysis indicated that there was no significant difference between the mean scores of "T-PFLS"; however, there was a statistically significant difference between the mean scores of "T-BRS" with regard to gender. The male participants' mean scores were higher than those of the female participants. The analysis revealed statistically significant differences in "T-PFLS" and "T-BRS" mean scores with respect to the position at the university. ANOVA analysis indicated statistically significant differences in mean scores of "T-PFLS" and "T-BRS" with respect to leisure participation preference. The mean scores of frequent participants were higher than the others in both of the scales. There was a statistically significant positive and moderate correlation between the mean scores of "T-PFLS" and "T-BRS" scores.

Conclusions: As a result, active participants reported higher perceived freedom and psychological resilience scores.

Key words: physical activity, leisure, perceived freedom, psychological resilience.

\section{article details}

Article statistics:

Full-text PDF:

Copyright

Indexation:

Funding:

Conflict of interests:

Corresponding author:

Open Access License:

Word count: 3,722; Tables: 6; Figures: 0; References: 67

Received: February 2021; Accepted: March 2021; Published: September 2021

http://www.balticsportscience.com

(c) Gdansk University of Physical Education and Sport, Poland

Celdes, Clarivate Analytics Emerging Sources Citation Index (ESCI), CNKI Scholar (China National Knowledge Infrastructure), CNPIEC, DOAJ, EBSCO - Central \& Eastern European Academic Source, EBSCO - SPORTDiscus, EBSCO Discovery Service, Google Scholar, Index Copernicus, J-Gate, Naviga (Softweco, Primo Central (ExLibris), ProQuest - Family Health, ProQuest - Health \& Medical Complete, ProQuest - Illustrata: Health Sciences, ProQuest Nursing \& Allied Health Source, Summon (Serials Solutions/ProQuest, TDOne (TDNet), Ulrich's Periodicals Directory/ ulrichsweb, WorldCat (OCLC)

This research received no specific grant from any funding agency in the public, commercial, or not-for-profit sectors. Authors have declared that no competing interest exists.

Prof. Dr. Bulent Gurbuz - Ankara University, Faculty of Sport Sciences, Turkey; e-mail: bgurbuz@ankara.edu.tr; phone number: +90 312 2211601/1621; fax number: +90 (312) 2122986

This is an open access article distributed under the terms of the Creative Commons Attribution-Non-Commercial-NoDerivatives 4.0 International (https://creativecommons.org/licenses/by-nc-nd/4.0/), which permits use, distribution and reproduction in any medium, provided the original work is properly cited, the use is non-commercial and is otherwise in compliance with the license. 


\section{INTRODUCTION}

Recently, changes experienced in science and technology lead to an increase individuals' leisure time [1, 2]. This increase, which occurred as a result of the changes [3, 4], has positively affected the life quality of individuals along with the use of leisure time [5]. In addition, the fact that individuals are in search of making use of leisure times has also created an interest especially in leisure physical activities [6]. On the other hand, there are also situations that emerge as a result of liabilities such as business workload and familial responsibilities for individuals. The need for leisure activities of individuals who wish to get rid of the existing situations for a moment also makes these activities become important [7].

Torkildsen [8] said that being relieved from responsibilities made leisure attractive and he defined leisure as the time remaining after work or after the fulfillment of mandatory social tasks, elected without restrictions $[9,10]$ or the time after these activities. On the other hand, Harmandar Demirel, Demirel and Serdar [11] argued that leisure time was generally the opposite of working. It was mentioned in previous studies that leisure time, which is associated with a sense of happiness and ability to develop, can also be a great source of joy and achievement [12].

Gurbuz and Henderson [13] associated leisure with individuals' perceptions of this time. 'How leisure is perceived' and 'how it emerged' depends on the basic conditions that lead to this time, like perceived freedom and intrinsic motivation [2]. During leisure, we experience positive emotions, like joy, self-expression, sense of identity, intrinsic motivation and perceived freedom associated with them [12]. In this context, individuals consider the sense of freedom in their leisure times to meet their intrinsic needs and acquire the highest benefit [14] because when they do not depend on an external reward, the perceived sense of freedom, pleasure, and satisfaction increases [15]. Neulinger described the perceived freedom, which comes into being as an important dimension of understanding leisure behavior [16], as a situation in which one feels that what s/he does is in line with his/her preference and because s/he wants to do it [as cited in: 17]. According to another description, it is a cognitive and motivational structure about the perceptions of participants in leisure time activities within their preferences [18]. The most important reason why individuals are physically active in their leisure is motivation [19]. Reyes Uribe [20] stated in her study that there is evidence that the health development of older adults triggers their leisure motivation (especially physical leisure time participation). Leisure activities are those preferred by individuals to perform during this time, independently from their work or other types of tasks [21]. Individuals establish social relationships, feel positive feelings, gain additional knowledge and skills so they improve their quality of life with the help of participation in leisure activities [22]. Besides, it was previously reported that these activities support positive feelings and life satisfaction [23-25] and reduce negative feelings [23].

Difficulties, which emerge due to reasons such as the working environment, personal life, and rapid social changes put pressure on people. For this reason, resilience appears as one of life requirements in our present day [26]. It was reported in previous studies that positive feelings like happiness provide innovative thoughts and actions that accumulate over time to build resilience [27]. Mental, social and physical characteristics all play important roles in maintaining resilience [28]. In this context, stress must be taken into account to understand the contribution of leisure experiences to health, because it is stated that chronic stress will cause psychological disorders, which increase the probability of mental and physical illness unless addressed [29]. Psychological resilience is briefly defined as disease resistance, adaptation, development, or the ability to relieve stress or to recover [30]. It is also an indicator of an individual's adaptation capacity in the face of stress in terms of personality traits [31]. In addition, resilience is also defined as an individual's successful recovery from a negative situation [32]. 
Strategies for managing leisure function as a systematic way to deal with stress factors [33]. Motivation to improve health, to relax, and be included in the society enable individuals to continue regular physical activities in their leisure times [34]. In dealing with stress, physical activity increases physical-psychological resilience and is also effective in developing resilience. Moreover, it is also seen that it decreases the negativity that might be caused by risk factors on individuals psychologically and biologically, and supports protective factors that describe individual, familial and environmental factors as a protection in the face of negative situations [35, 36]. Although it is difficult to measure the psycho-social effects on individuals, exercise is important for the protection of psychosocial health, "for reducing anxiety, stress and depression, maintaining mental health" with its positive effects on social health [37]. Also, it was reported that recreation programs can reduce perceived stress, anxiety, depression and negative mood [38, 39]. Considering recreational activities as protective factors for good health and wellbeing is essential for lifelong ideal development because it supports resilience [40].

Leisure activities are among the areas that were created to stimulate the social lives of individuals, to help protect their physical and mental health, and to improve the quality of life [8]. Options of activity vary according to the wishes, needs, preferences and abilities of individuals in the scope of resting, entertainment and creativity [41]. Participation in outdoor and physical activities requires physical health, and home-focused participation in social events is positively associated with a good mental health [42]. In addition, satisfactory experience achieved as a result of participation in these activities also enables coping with obstacles [43]. On the other hand, the positive experiences that are obtained with participation in activities also improve the quality of life by contributing to individuals in both physical and psychological terms [44].

Right at this point, the place and importance of leisure activities (i.e., physical activities) in our lives are revealed, and the benefits of these activities in protecting or improving physical and psychological health of individuals attract the attention. As a result of the literature review, studies conducted on the relationship between freedom, happiness and satisfaction perceived in leisure emphasize the importance of our study. In this context, the purpose was to compare the freedom and resilience levels of university personnel perceived in leisure with some variables and to examine the relations between these two variables.

\section{MATERIAL AND METHODS}

\section{RESEARCH MODEL}

The present study used a correlational survey method, which is frequently used in the fields of education and social sciences to examine the relationships and connections between variables, and which is a quantitative research method [45]. There is no interference in phenomena in correlational studies, and the main aim is to determine the degree of change between the examined parameters. Not only the cause-and-effect relation but also the change of the variables together are investigated in correlational studies [46].

\section{PARTICIPANTS}

The study group consisted of 270 staff, 97 of whom were women $\left(\mathrm{M}_{\text {age }}=34.75, \mathrm{SD}=6.07\right)$ and 173 were men $\left(\mathrm{M}_{\text {age }}=36.87, \mathrm{SD}=7.88\right)$. The mean age for the whole sample was 36.11 . The participants worked at a state university. Among these, 189 (70\%) were academic, and $81(30 \%)$ were administrative staff. The group was selected with a convenient sampling technique, which is one of the improbable sampling methods. 


\section{PROCEDURES}

The study form that was used in the study consisted of three separate sections. The first section included questions on gender, age, position at the university, and the frequency and preference in participation in leisure activities. For the other two sections, information about the measurement tools in the study is presented below.

Perceived Freedom in Leisure Scale (T-PFLS): This scale was developed to determine the perceived freedom levels in leisure [47] and was adapted into Turkish as a brief form [43]. The scale items are in 5-point Likert form, and there are a total of 25 items in this scale, which are rated as; "Absolutely Disagree (1)" and "Absolutely Agree (5)". This scale has a single sub-dimension structure. The internal consistency coefficient of the original scale amounted to 0.93 .

Brief Resilience Scale (T-BRS): The resilience of the academic and administrative personnel who participated in the study was measured by using T-BRS, which was developed by Smith et al. [30]. The adaptation of the scale into the Turkish culture was conducted by Doğan [32]. There are a total of 6 items in the scale. The items of the scale are scored as "Not suitable (1)" to "Completely suitable (5)" in a 5-point Likert style, and items 2, 4 and 6 are reverse-coded. The Cronbach Alpha internal consistency coefficient of the original scale amounted to 0.83 .

\section{STATISTICAL ANALYSIS}

The researchers applied the measurement tools in face-to-face interviews with the participants, after the necessary permissions from the relevant departments of university administration were obtained. The scales were distributed to the academic and administrative staff during working hours and were then re-collected. An instruction section was established on the first page of the measuring tool and the necessary explanations were made to the participants included in the study. The basic principle was that the academic and administrative personnel volunteered to participate in the study. A total of 350 questionnaires forms were distributed to the participants, but some of these scales did not come back or were not included in the study because they were incomplete.

The analysis of all the data, transferred to an online form, was done with SPSS 21.00 statistical package program. Normal distribution assumptions of the independent variables for each scale were examined by calculating the Skewness-Kurtosis values. For the variable to be considered sufficiently symmetrical, skewness and kurtosis values were expected to be between -1.96 and +1.96 [48]. To test the differences between the mean scores of the independent variables one-factor variance analysis (One-Way ANOVA), independent samples t-test and Product-Moment Correlation Coefficient hypothesis tests were performed as the statistical methods. The Cronbach's Alpha analysis method was applied in testing the reliability of the scales. The reliability coefficient calculated for a psychological test of 0.70 or higher is generally considered sufficient for the reliability of the test scores. [49].

\section{RESULTS}

In the study, which was conducted to determine the relationships between freedom levels and resilience perceived in leisure times of academic and administrative staff working at the university, comparisons were made between gender, the position at the university, the frequency of participation in physical activity, and the preference of participation in physical activity. The results of this study show that the levels of freedom and resilience of the participants perceived at leisure time are moderate. 
The findings and comments obtained in this part of the present study are given in the tables, respectively. The distribution of T-PFLS and T-BRS scale scores is given in Table 1.

Table 1. Descriptive Statistics of the Variables

\begin{tabular}{cccccccccc} 
Scales & $\begin{array}{c}\text { Number } \\
\text { of items }\end{array}$ & N & M & SD & Skewness & Kurtosis & Min. & Max. & $\begin{array}{c}\text { Cronbach's } \\
\text { Alpha }\end{array}$ \\
\hline T-PFLS & 25 & 270 & 3.59 & 0.54 & -.0433 & 0.788 & 1.76 & 4.84 & 0.91 \\
T-BRS & 6 & 270 & 3.39 & 0.71 & -0.455 & 0.628 & 1.00 & 5.00 & 0.71 \\
\hline
\end{tabular}

When the distribution of scale scores were evaluated, it was seen that the arithmetic mean of the total scores received from the T-PFLS was 3.60, and the standard deviation was 0.54 . The lowest mean score of the university staff included in the study was 1.76 , and the highest mean score was 4.84 . When the Skewness $(-0.433)$ and Kurtosis $(0.788)$ values calculated for the measuring instruments are examined, it can be argued that the data meets the normality assumption. The internal consistency for the whole scale (i.e., 27 items) was $\alpha=.86$.

Similarly, the arithmetic mean of the total scores received by the participants from the T-BRS was 3.39, and the standard deviation was 0.71 . The lowest score of the university staff included in the study received from the scale was 1.00, and the highest score was 5.00. When the calculated Skewness $(-0.455)$ and Kurtosis $(0.628)$ values for T-BRS were examined, it was determined that the data were distributed normally. The internal consistency for the T-BRS was calculated as $\alpha=0.71$.

Table 2. Independent Samples T-Test by Gender

\begin{tabular}{|c|c|c|c|c|c|c|}
\hline \multirow{2}{*}{ Scales } & \multicolumn{2}{|c|}{$\begin{array}{c}\text { Male } \\
(n=97)\end{array}$} & \multicolumn{2}{|c|}{$\begin{array}{c}\text { Female } \\
(n=173)\end{array}$} & \multirow{2}{*}{$\mathrm{t}$} & \multirow{2}{*}{$p$} \\
\hline & $M$ & SD & $M$ & SD & & \\
\hline T-PFLS & 3.61 & 0.50 & 3.60 & 0.56 & 0.06 & 0.95 \\
\hline T-BRS & 3.23 & 0.68 & 3.48 & 0.72 & 2.77 & 0.00 \\
\hline
\end{tabular}

The results of t-test analysis for independent samples indicated that the T-PFLS scores of the participants did not significantly differ in terms of the gender independent variable $\left(\mathrm{t}_{268}=0.06 ; \mathrm{p}>0.05\right)$; however, T-BRS scores differed at statistically significant levels $\left(t_{268}=2.77 ; p>0.01\right)$. In this scale, where the difference was found, the mean score of the male participants was higher than that of the women.

Table 3. Independent Samples T-Test by Position at the University

\begin{tabular}{|c|c|c|c|c|c|c|}
\hline \multirow{2}{*}{ Scales } & \multicolumn{2}{|c|}{$\begin{array}{c}\text { Academic } \\
(n=189)\end{array}$} & \multicolumn{2}{|c|}{$\begin{array}{l}\text { Administrative } \\
(n=81)\end{array}$} & \multirow[t]{2}{*}{$t$} & \multirow{2}{*}{$p$} \\
\hline & $M$ & SD & $M$ & SD & & \\
\hline T-PFLS & 3.65 & 0.51 & 3.50 & 0.58 & 2.03 & 0.04 \\
\hline T-BRS & 3.50 & 0.74 & 3.15 & 0.58 & 3.77 & 0.00 \\
\hline
\end{tabular}

The t-test was applied for independent samples to determine the statistically significant difference of T-PFLS and T-BRS scores according to the position in university. According to the analysis results, the mean scores of the academic and administrative staff differed at statistically significant levels as t-PFLS $\left(\mathrm{t}_{268}=2.03 ; \mathrm{p}<0.05\right)$ and T-BRS $\left(\mathrm{t}_{268}=3.77 ; \mathrm{p}<0.01\right)$ depending on the position at the university. The mean scores of university administrative staff in T-PFLS and T-BRS were lower than those of the academic staff. 
One-Way ANOVA was used to examine whether the participants' levels of freedom and resilience perceived in leisure time differed at statistically significant levels depending on the frequency of participation in physical activity. The analysis revealed that the T-PFLS scores of the participants differed at statistically significant levels depending on the variable frequency of participation in physical activity $\left(\mathrm{F}_{267}=6.938, \mathrm{p}<0.05\right)$. Based on posthoc comparisons, it was found that the mean scores of the participants who took part in physical activities frequently in their leisure time differed in a statistically significant way compared to those who took part in physical activities sometimes, and to those who did not take part in such activities at all. The mean scores of those who frequently undertook physical activities were higher than of the other two groups (Table 4). In addition, it was also found that the participants' T-BRS scores differed at statistically significant levels depending on the frequency of participation in physical activities $\left(\mathrm{F}_{267}=8.704, \mathrm{p}<0.05\right)$, and there were statistically significant differences between the mean scores of those who did not participate in physical activities at all and those who participated in physical activity frequently and sometimes (Table 4).

Table 4. ANOVA by Frequency of Participation in Physical Activity

\begin{tabular}{|c|c|c|c|c|c|c|c|c|}
\hline \multirow{2}{*}{ Scales } & \multicolumn{2}{|c|}{$\begin{array}{c}\text { Never } \\
(n=49)\end{array}$} & \multicolumn{2}{|c|}{$\begin{array}{l}\text { Sometimes } \\
(n=158)\end{array}$} & \multicolumn{2}{|c|}{$\begin{array}{l}\text { Frequently } \\
\quad(n=63)\end{array}$} & \multirow{2}{*}{$\mathrm{t}$} & \multirow{2}{*}{$p$} \\
\hline & $M$ & SD & $M$ & SD & $M$ & SD & & \\
\hline T-PFLS & 3.44 & 0.71 & 3.58 & 0.48 & 3.80 & 0.47 & 6.938 & 0.01 \\
\hline T-BRS & 3.06 & 0.68 & 3.41 & 0.68 & 3.61 & 0.73 & 8.704 & 0.01 \\
\hline
\end{tabular}

The t-test results with regard to participation preference to leisurely physical activities are given in Table 5. The analysis indicated that T-PFLS scores did not significantly differ $\left(\mathrm{t}_{268}=0.40 ; \mathrm{p}<0.05\right)$; however, T-BRS scores differed statistically significantly $\left(\mathrm{t}_{268}=3.51\right.$; $\mathrm{p}<0.01$ ). The mean resilience scores of the staff who participated in leisure activities passively were higher than of those who participated actively.

Table 5. Independent Samples of T-Test by Preference of Participation in Physical Activity

\begin{tabular}{|c|c|c|c|c|c|c|}
\hline \multirow{2}{*}{ Scales } & \multicolumn{2}{|c|}{$\begin{array}{l}\text { Active } \\
(n=159)\end{array}$} & \multicolumn{2}{|c|}{$\begin{array}{c}\text { Passive } \\
(n=111)\end{array}$} & \multirow[t]{2}{*}{$\mathrm{t}$} & \multirow{2}{*}{$p$} \\
\hline & M & SD & $M$ & SD & & \\
\hline T-PFLS & 3.61 & 0.54 & 3.59 & 0.53 & 0.40 & 0.68 \\
\hline T-BRS & 3.27 & 0.73 & 3.57 & 0.65 & 3.51 & 0.00 \\
\hline
\end{tabular}

The Pearson correlation analysis was done to test a relationship between perceived freedom and resilience scores. According to the analysis results, it was found that there was a positive and moderately significant correlation between the participants' perceived freedom scores and resilience scores $(\mathrm{r}=0.331, \mathrm{p}<0.01)$. According to this result, it can be argued that as the perceived freedom scores of the participants increase, so will their resilience scores.

Table 6. Correlation between T-PFLS and T-BRS

\begin{tabular}{ccc} 
& T-PFLS & T-BRS \\
\hline T-PFLS & 1 & \\
T-BRS & $0.33^{* *}$ & 1 \\
\hline
\end{tabular}




\section{DISCUSSION}

The findings obtained in the study suggest that the scores of participants in perceived freedom in leisure did not differ at significant levels according to the gender variable. This result is similar to the results of many previous studies in the literature [11, 16]. However, in another study conducted by Yerlisu Lapa [50], it was reported that perceived freedom varied significantly according to the gender, and that women had higher perception scores in freedom. Janke, Carpenter, Payne and Stockard [51] argued that freedom and personal preferences were important in the leisure time perceptions of middle-age women, and that many factors, including gender, could affect perceived freedom in leisure time. Another finding of our study was that the mean scores of male participants in the resilience scale were higher than those of women. Although there are many studies reporting similar results in the literature [52-54], there are also several other studies speculating that women are psychologically stronger than men. It is possible to argue that this difference stemmed from the fact that our study was conducted with older adults. Because higher resilience levels were associated with increased age [28].

Another finding of the study was related to the frequency of participation in leisure activities. It is possible to argue that individuals who frequently participate in physical activity in their leisure time have higher perceptions of freedom and resilience scores. In this context, as the frequency of participation in leisure activities increases, the perceived levels of freedom and resilience also increase. When the literature was reviewed, it was observed that there are several studies showing results similar to our study in terms of perceived freedom and physical activity variables [55]. On the other hand, Denovan and Macaskill [56] reported that participation in leisure time activities could be an important source in coping with stress. It was determined in previous studies that individuals with high resilience levels had higher problem-solving abilities and could fight problems better [57]. Since the initial studies conducted on resilience were aimed at how it appeared in children and adolescents, a better understanding is considered as a requirement in adult groups in our country [58]. Furthermore, resilience is considered as an important predictor to increase subjective well-being [59]. The leisure time perceptions of individuals who participate in physical activities in their leisure times are positively affected [55], and their psychological well-being levels are increased [60]. On the other hand, the satisfaction obtained from these activities contributes to the positive effects of individuals in leisure time and their subjective well-being at significant levels [61]. According to Argan, Tokay Argan and Dursun [62], leisure and life satisfaction are among the factors that determine the dimensions of happiness. The increased leisure satisfaction levels also increase the perceived freedoms of individuals in leisure times [63]. It was also reported that increased satisfaction in leisure increased the satisfaction in life, and as a result, freedom perceived in leisure was positively affected [55].

When the freedom scores perceived according to the way the participants took part in leisure time activities were examined, the mean scores of those who actively took part in activities were higher than those who participated passively. Sarol and Çimen [64] said individuals needed leisure time and were able to fulfill themselves by participating in active or passive leisure activities. In different studies, the higher freedom perception levels of individuals who actively participated in sports and social and cultural activities [63] were similar to those found in our study. On the other hand, according to some previous studies, it was determined that university students preferred participation in passive, indoor and home-based activities. The basic reason for this may be explained as that the leisure time demands were affected by easy access and low socio-economic situation [65, 16]. 


\section{CONCLUSIONS}

According to the results obtained in the present the study, it was concluded that there was a positive and significant relationship between the freedom and resilience of the participants perceived in leisure. When the literature was reviewed, it was determined that there are many studies conducted on the perception of resilience and leisure boredom perception [53], happiness [27], life satisfaction [66], and leisure constraints [67]. In this respect, it is possible to find studies that directly demonstrate the relation between perceived freedom, resilience and participation in leisure activities in the literature in limited numbers. For example, the studies conducted by Aydın et al. [53] reported that the individuals participating in leisure activities had higher resilience scores, which is similar to our study. On the other hand, among studies on perceived freedom there are those reporting positive relationships between participation in leisure time activities and perceived freedom [16].

The formation of the study group only with academic and administrative staff at public universities can be considered as a limitation of the study. Based on the results of this study and previous studies, it may be speculated that demographic characteristics constitute a factor that causes differences in leisure behavior. It is possible that the changes in social life with the participation in leisure activities will have positive effects like protecting and increasing the physical and psychological health of individuals. In this context, individuals should be encouraged to participate in more leisure activities to contribute to their resilience and increase freedom perceptions. For this reason, it is important that future studies are conducted not only at universities but also in all public institutions and organizations to allow making use of leisure more effectively and efficiently and also to contribute to individual, familial and business life. In addition, it is also considered that it is important to introduce programs to increase the participation in leisure activities and to shape the activity contents offered by universities according to the needs and expectations of individuals. In future studies, the current status of different universities, public institutions and organizations regarding the study topic can be investigated. Examining the topic of the study in broader sampling groups and different variables can provide its better understanding. Qualitative studies can also be conducted to understand how participation in physical activity creates a sense of freedom in individuals and the positive psychological effects of participation. In addition, it is considered that the effective and efficient use of leisure time should be emphasized by comparing existing and future studies.

\section{REFERENCES}

[1] Kara FM, Gürbüz B, Küçük-Kılıç S, Öncü, E. An investigation of pre-service physical education teachers' leisure boredom, life satisfaction and social connectedness. J Computer Educ Res. 2018;6(12):342-357. https://doi. org/10.18009/jcer.466740

[2] Webb E, Karlis, G. Theoretical developments in leisure studies: a look at perceived freedom and intrinsic motivation. Loisir et Société/Society and Leisure. 2017;40(2):268-283. https://doi.org/10.1080/07053436.2017.1328790

[3] Roberts K. Writing about leisure. World Leisure J. 2018;60(1):3-13. https://doi.org/10.1080/16078055.2016.1261645

[4] Yetim G, Argan M. The relationship between satisfaction and loyalty towards to the fitness center with the factors of leisure involvement. Anadolu University Journal of Social Science. 2018;18(1):49-62. https://doi.org/10.18037/ ausbd.550625

[5] Güngörmüş HA, Yenel F, Gürbüz B. Examination of recreational motives of individuals: demographic differences. Int J Human Sci. 2014;11(1):373-386.

[6] Koçak F, Gürbüz B, Doğaner S, Özbek O. Relationship among leisure facilitators, leisure constraints, and leisure involvement: structural equation modelling study. 16th International Sports Sciences Congress; 2018 October 31-3; Antalya, Turkey.

[7] Kara, FM, Gürbüz, B, Öncü, E. Work hard, play hard: leisure satisfaction and work engagement among Turkish women. Work: A Journal of Prevention Assessment \& Rehabilitation. 2019;64(2)177-185. https://doi.org/10.32323/WOR-192979

[8] Torkildsen G. Leisure and recreation management. 5th ed. Taylor \& Francis e-Library; 2005.

[9] Haworth J, Lewis S. Work, leisure and well-being. Br J Guid Counsel. 2010;33(1):67-69. https://doi.org/10.1080/03 069880412331335902 
[10] Hills P, Argylea M, Reeves R. Individual differences in leisure satisfactions: an investigation of four theories of leisure motivation. Personal Indiv Differences. 2000;28:763-779. https://doi.org/10.1016/S0191-8869(99)00137-3

[11] Harmandar Demirel D, Demirel M, Serdar E. University students' opinions of the meaning of and their perceived freedom in leisure. J Human Sci. 2017;14(1):796-802. https://doi.org/10.14687/jhs.v14i1.4341

[12] Dattilo J. Positive psychology and leisure education, a balanced and systematic service delivery model. Recreation J. 2015;49(2):148-165

[13] Gurbuz B, Henderson K. Exploring the meanings of leisure among Turkish university students. Croat J Educ. 2013;15(4):927-957.

[14] Ellis GD, Witt PA. The measurement of perceived freedom in leisure. J Leisure Res. 1984;16(2):110-123. https://doi. org/10.1080/00222216.1984.11969595

[15] Cordes AK. The nature of leisure, recreation, and play, applications in recreation \& leisure for today and the future. 4nd ed. Sagamore Publishing LLC; 2013.

[16] Wu HC, Liu A, Hung Wang C. Taiwanese university students' perceived freedom and participation in leisure. Ann Leisure Res. 2010;13(4):679-700. https://doi.org/10.1080/11745398.2010.9686870

[17] Siegenthaler KL, O’ Dell I. Leisure attitude, leisure satisfaction, and perceived freedom in leisure within family dyads. Leisure Sci. 2000;22:281-296. https://doi.org/10.1080/01490409950202302

[18] Ağyar E. Contribution of perceived freedom and leisure satisfaction to life satisfaction in a sample of Turkish women. Soc Indicat Res. 2014;116:1-15. https://doi.org/10.1007/s11205-013-0268-0

[19] Molanorouzi K, Khool S, Morris T. Validating the physical activity and leisure motivation scale (PALMS). BMC Public Health. 2014;14:909. https://doi.org/10.1186/1471-2458-14-909

[20] Reyes Uribe AC. Theinfluence of psychological needs in Mexican older adults' leisure motivations. Leisure Sci. 2018;40:6:601-616. https://doi.org/10.1080/01490400.2017.1325797

[21] Mouratidis K. Built environment and leisure satisfaction: the role of commute time, social interaction, and active travel. J Transport Geography. 2019;80:102491. https://doi.org/10.1016/j.jtrangeo.2019.102491

[22] Brajša-Žganec A, Merkaš M, Šverko I. Quality of life and leisure activities: how do leisure activities contribute to subjective well-being? Soc Indicat Res. 2011;102(1):81-91.

[23] Newman DB, Louis Tay I, Diener E. Leisure and subjective well-being: a model of psychological mechanisms as mediating factors. J Happiness Stud. 2014;15:555-578. https://doi.org/10.1007/s10902-013-9435-x

[24] Sarol H, Aydın İ, Gürbüz B, Çimen Z. Life satisfaction and job satisfaction: in relation to recreational physical activity. 13th International Sports Sciences Congress; 2014 November 7-9; Konya, Turkey.

[25] Sato M, Yoshida M, Wakayoshi K, Shonk DJ. Event satisfaction, leisure involvement and life satisfaction at a walking event: the mediating role of life domain satisfaction. Leisure Studies. 2017;36(5):605-617. https://doi.org/10.1080/ 02614367.2016 .1240221

[26] Ghamsari MS, Lavasani MG. Effectiveness of emotion freedom technique on pregnant women's perceived stress and resilience. J Educac Sociol. 2015;6:2.

[27] Short CA, Barnes S, Carson JF, Platt I. Happiness as a predictor of resilience in students at a further education college. Journal of Further and Higher Education 2020;44(2):170-184. https://doi.org/10.1080/0309877X.2018.1527021

[28] MacLeod S, Musich S, Hawkins K, Alsgaard K, Wicker ER. The impact of resilience among older adults. Geriatric Nurs. 2016;37:266-272. https://doi.org/10.1016/j.gerinurse.2016.02.014

[29] Coleman DJ. Health. In: Jenkins MJ, Piagram JJ, editors. Encyclopedia of leisure and outdoor recreation. Taylor \& Francis e-Library; 2005, 221-222.

[30] Smith WB, Dalen J, Wiggins K, Tooley E, Christopher P, Bernard J. The brief resilience scale: assessing the ability to bounce back. Int J Behav Med. 2008;15:194-200. https://doi.org/10.1080/10705500802222972

[31] Çapan EB, Arıcıoğlu A. Forgiveness as predictor of psychological resiliency. e-Int J Educ Res. 2015;5:4:70-82.

[32] Doğan T. Adaptation of the Brief Resilience Scale into Turkish: A validity and reliability study. J Happiness WellBeing. 2015;3(1):93-102.

[33] Nagata S, McCormick BP, Piatt J. The impact of decreased capacity to experience pleasure on leisure coping strategies among individuals with major depressive disorder. Leisure Sci. 2018. https://doi.org/10.1080/01490400.2018.1458667

[34] Bartolj T, Slabe-Erker R. Differences in leisure time physical activity predictors in Europe. Pol Sociol Rev. 2015;190:239 254.

[35] Özer E. Core self evaluations, coping strategies and psychological resilience. Turkish Studies, International Periodical Fort the Languages, Literature and History of Turkish or Turkic. 2016;11(14):587-606. https://doi.org/10.7827/ TurkishStudies.9536

[36] Şahin M, Yetim AA, Çelik A. Physical activity and sport as a preventive factor in building resilience. The Journal of Academic Social Science Studies. 2012;5(8):373-380. https://doi.org/10.9761/jasss 405

[37] Özden A. Psychosocial health and exercise. J Physiother Rehabil-Special Topic. 2016;2:1:122-6.

[38] Fenton L, White C, Hamilton-Hinch B, Gilbert R. The impacts of recreation programs on the mental health of postsecondary students in North America: an integrative review. Leisure Sci. 2018. https://doi.org/10.1080/01490 400.2018.1483851

[39] Kocak F. The relationship between leisure constraints, constraint negotiation strategies and facilitators with recreational sport activity participation of college students. College Student J. 2017;51(4):491-497.

[40] Hutchinson S, Robertson B. Leisure Education: A new goal for an old idea whose time has come. Pedagogía Social. Revista Interuniversitaria 2012;19:127-139. https://doi.org/10.7179/PSRI 2012.19.09

[41] Sivevska D, Popeska B, Gregorc J, Ignatov G. Leisure time activities of students at teaching faculties from three countries. New Trends and Issues Proceedings on Humanities and Social Sciences. 2017;1:452-462. https://doi. org/10.18844/gjhss.v3i1.1803

[42] Kim J, Heo J, Dvorak R, Ryu J, Han A. Benefits of leisure activities for health and life satisfaction among Western migrant. Ann Leisure Res. 2018;21(1):47-57. https://doi.org/10.1080/11745398.2017.1379421 
[43] Yerlisu Lapa T, Tercan Kaas E. Serbest zamanda algılanan özgürlük ölçeği: yapı geçerliğinin sınanması [Freedom scale perceived in leisure time: Testing construct validity]. Dünya Spor Bilimleri Araştırmaları Kongresi; 2017 Kasım 23-26; Manisa, Türkiye. Turkish.

[44] Sato M, Jordan JS, Funk DC. The Role of physically active leisure for enhancing quality of life. Leisure Sci. 2014;36(3):293-313. https://doi.org/ 10.1080/01490400.2014.886912

[45] Sönmez V, Alacapınar GF. Örneklendirilmiş Bilimsel Araştırma Yöntemleri [Illustrated Scientific Research Methods. 4th edition]. 4. ed. Ankara: Anı Yayıncılık; 2016. Turkish.

[46] Büyüköztürk Ş, Kılıç Çakmak E, Akgün ÖE, Karadeniz Ş, Demirel F. Bilimsel Araştırma Yöntemleri [Scientific Research Methods]. 1.ed. Ankara: Pegem Akademi; 2008. Turkish.

[47] Witt PA, Ellis GD. Development of a short form to assess perceived freedom in leisure. J Leisure Res. 1985;17(3):225-233. https://doi.org/10.1080/00222216.1985.11969632

[48] Kline RB. Principles and practice of structural equation modeling. New York: Guilford Press; 2011.

[49] O'Donoghue P, Holmes L. Data analysis in sport. London \& Newyok: Routledge; 2014. https://doi.org/10.4324/9781315816357

[50] Yerlisu Lapa T. Life satisfaction, leisure satisfaction and perceived freedom of park recreation participants. Procedia - Soc Behav Sci. 2013;93:1985-1993.

[51] Janke MC, Carpenter G, Payne LL, Stockard J. The role of life experiences on perceptions of leisure during adulthood: a longitudinal analysis. Leisure Sciences 2010;33(1):52-69. https://doi.org/10.1080/01490400.2011.533108

[52] Avcı Taşkıran T, Gürbüz B. Predictive power of leisure satisfaction on perceived social competence and resilience. 2th. International Congress on Recreation and Sport Management; 2019 April 11-14; Muğla, Turkey.

[53] Aydın İ, Öncü E, Akbulut V, Küçük Kılıç S. Öğretmen adaylarında boş zaman sıkılma algısı ve psikolojik sağlamlık ilişkisi [The relationship between teacher candidates' perception of leisure time boredom and psychological resilience]. Atatürk Üniversitesi Beden Eğitimi ve Spor Bilimleri Dergisi. 2019;21(1):39-53. Turkish.

[54] Hoşoğlu R, Fırıncı Kodaz A, Yılmaz Bingöl T, Vural Batık M. Öğretmen adaylarında psikolojik sağlamlık [Psychological resilience of teacher candidates]. Uluslararası Toplum Araştırmaları Dergisi. 2018;8(14):217-239. Turkish.

[55] Güngörmüş HA, Işık U, Şebin K, Aydın M. Doğa sporu yapan bireylerin serbest zaman doyum düzeylerinin yaşam doyumu üzerindeki etkisi: serbest zamanda algılanan özgürlüğün aracılık rolü [The effect of leisure time satisfaction levels of individuals engaged in outdoor sports on life satisfaction: the mediating role of perceived freedom in leisure time]. 2. Uluslararası Rekreasyon ve Spor Yönetimi Kongresi [2nd International Recreation and Sports Management Congress]; 2019 April 11-14; Muğla, Türkiye. Turkish.

[56] Denovan A, Macaskill A. Building resilience to stress through leisure activities: A qualitative analysis. Ann Leisure Res. 2017;20(4):446-466. https://doi.org/10.1080/11745398.2016.1211943

[57] Öz F, Yılmaz Bahadır E. Ruh sağlığının korunmasında önemli bir kavram: psikolojik sağlamlık (derleme) [An important concept in the protection of mental health: resilience (review)]. Hacettepe Üniversitesi Sağlık Bilimleri Fakültesi Hemşirelik Dergisi. 2009;82-89. Turkish.

[58] 58. Karaırmak Ö, Siviş Çetinkaya R. Benlik saygısının ve denetim odağının psikolojik sağlamlık üzerine etkisi: duyguların aracı rolü [The effect of self-esteem and locus of control on resilience: the mediating role of emotions] Türk Psikolojik Danışma ve Rehberlik Dergisi. 2011;4(35):30-43. Turkish.

[59] Satıcı SA. Psychological vulnerability, resilience and subjective well-being: the mediating role of hope. Personality Indiv Differ. 2016;102:68-73. https://doi.org/10.1016/j.paid.2016.06.057

[60] Gürbüz B, Ayverdi B, Koçak F. Psikolojik iyi oluş ve serbest zamanda sıkılma algısı ilişkisi: Türkiye perspektifi [The relationship between psychological well-being and the perception of boredom in leisure time: Turkish perspective] II. Dünya Spor Bilimleri Araştırmaları Kongresi, 2019 Mart 21-24; Manisa, Türkiye. Turkish.

[61] Sirgy MJ, Uysal M, Kruger S. Towards a benefits theory of leisure well-being. Applied Research Quality Life 2017; 12:205-228. https://doi.org/10.1007/s11482-016-9482-7

[62] Argan M, Tokay Argan M, Dursun MT. Examining relationships among well-being, leisure satisfaction, life satisfaction, and happiness. Int J Med Res Health Sci. 2018;7(4):49-59.

[63] Serdar E, Mungan Ay S. Üniversite öğrencilerinin serbest zaman etkinliklerine katılım biçimlerine göre tatmin olma ve algılanan özgürlük düzeylerinin incelenmesi [Examination of satisfaction and perceived freedom levels of university students according to their participation in leisure activities]. Sosyal Bilimler Dergisi .2016;3(9):365-374. https:// doi.org/10.16990/SOBIDER.3332 Turkish.

[64] Sarol H, Çimen Z. Why people participate leisure time physical activity: a Turkish perspective. Pamukkale Journal of Sport Sciences 2017;8(1):63-72.

[65] Gürbüz B, Henderson AK. Leisure activity preferences and constraints: Perspectives from Turkey. World Leisure J. 2014;56(4):300-316. https://doi.org/10.1080/16078055.2014.958195

[66] Fountain AC, Roberts EP, Schuster G, Breitmeyer AM, Stein AB. Dental faculty, studen,t and alumni perceptions of happiness and life satisfaction in dental school: foundations for resilience and well-being. J Dental Educ. 2020;336342. https://doi.org/10.21815/JDE.019.181

[67] Güler C, Demirel Harmandar D, Cakır VO, Budak D. Leisure negotiation strategies with the leisure constraints: example of university students. Turkish Studies-Social Sciences. 2020;15(4):1919-1930. 